Roman Pavliuk

ORCID ID 0000-0002-8957-6158

$\mathrm{PhD}$ (Pedagogy), Associate Professor, Deputy Director for Scientific-Methodical and Educational Affairs,

Institute of Human Sciences, Associate Professor of English Language Department, Faculty of Law and International Affairs, Borys Grinchenko Kyiv University, 18/2 Ihor Shamo Blvd, 02154 Kyiv, Ukraine, r.pavliuk@kubg.edu.ua

\title{
RESEARCH-BASED TRAINING FOR PREPARATION OF PROFESSIONALS OF THE SOCIAL SPHERE IN GERMANY
}

The article deals with the educational systems of research-based training for preparation of specialists of social sphere in Germany. On the basis of the research of foreign scientists and previous researches of the author it was set that the system of research-based training is defined as a complex of pedagogical purposes, which are combined with the main tasks in the development of research competence of students (development of skills for setting the research task and finding ways to solve it). The system of research-based training for preparation of specialists of social sphere in two leading universities of Germany (University of Cologne (Cologne, Germany) and Humboldt University (Berlin, Germany)) has been analysed. It is established that not every Master's program involves studying with the use of research techniques. However, it was found that the research-based training system of study in its proper application encompasses not just the student's research activity partly detached from the educational process, but is reflected in each student's discipline. Each discipline reveals one of the aspects / tasks / areas of student research and in parallel serves as a practical basis for the development of professionally meaningful competences.

Prospects for further research we see the study of the individual research and educational trajectory of the student through the entire period of training in the research-based training system for specialists of the social sphere and the development of methodological recommendations for the use of such a trajectory and system in the Ukrainian system of higher education.

Key words: educational system; professional training; research-based training system; specialist of social sphere.

https://doi.org/10.28925/1609-8595.2019.1.7379

Introduction. The current changes in Ukraine's educational policy, in particular the training of future specialists in the higher education system, are primarily oriented towards European integration, that is, the preparation of a competitive specialist capable of carrying out professional activities in accordance with the requirements of modern society, of constant globalization processes and the withdrawal of the labour market to the European level. This reality is due not only to European integration processes, but also to the current state of development of institutions of higher education (IHE). IHE have primary task in reorientation of the content of preparation for the best European models, experience of European countries and many years of historical experience of such states. Such tasks arise not only because of the demand of the present but also declared in the basic normative legal acts of Ukraine: the Laws of Ukraine «On Higher Education» (2014), «On Scientific and Scientific and Technical Activities» (2015), «On Education» (2017) etc.

At the same time, an inclusive educational environment is actively developing in Ukraine, which is due to an increase in the number of children with special educational needs, people with disabilities who have the right to equal access to education. It is equal access to education for all categories of recipients of services today as an indicator of the civilization of society, its tolerance and high level of development. It should be noted that in the countries of the European Union this problem has long been solved by recognizing the high level of inclusiveness and through rethinking the system of training specialists in the social sphere that help children with special educational needs and people with disabilities to receive equal access to education, to socialize and integrate into society.

According to the Ministry of Education and Science of Ukraine in 2016/2017 the number of children enrolled in special classes of secondary schools is 5669 , which is $7 \%$ more than in $2015 / 2016$. The number of children studying in inclusive classes of secondary education institutions from 2015/2016 to date has increased by $35 \%$ and is 4180 (Ministry of Education and Science of Ukraine).

From these statistics, we understand that there is an urgent need for training professionals who will be able to provide the educational process in an inclusive environment at a high level and will help children with special needs and people with disabilities in equal 
access to education, socialization and integration into modern society. It is such a mission that relies on modern specialists of social sphere.

In general, the social sphere is a set of industries providing a variety of (material and spiritual) services for the population; a set of industries, enterprises, organizations that directly determine the way and standard of living of people, their well-being and satisfaction of different needs. These are different branches of human society, in which the social policy of the state is realized through the distribution of material and spiritual goods, ensuring the progress of all aspects of social life, improving the situation of man, labour. The social sphere covers the system of social, socioeconomic, national relations, communication of society and personality; the entire space of human life from the conditions of its work and life, health and leisure to social-class and socio-ethnic relations (Encyclopaedia, 2012, p. 96-98).

According to the education system defined above there are teachers in the inclusive / special class, social pedagogues, social workers and psychologists.

We understand that the activities of specialists of social sphere in the educational process are not limited to interaction with a child with special educational needs and people with disabilities, but also partly related to work with parents / guardians / family of such children, people. That is, the modern specialist in the social sphere should be able not only to integrate the child, a person into the educational environment, but also be able to carry out diagnostics, correction, planning of work with adults, assistance in providing social services and observance of rights in accordance with the regulatory framework, to do conclusions based on a set of actions, to conduct monitoring and evaluation, that is, to be capable of conducting certain researches, formulation of conclusions and recommendations.

From the above, it follows that the training of future specialists in the social sphere (assistant teacher in the inclusive / special class, social teacher, social worker, psychologist) should be aimed not only at the development of professionally relevant competencies, but also on the development of research techniques and skills, that is, with the active use of a research-based training system.

Today, this system of training specialists in the social sphere is applied in the leading countries of Europe and the European Union. This is confirmed in the works of Ukrainian and foreign researchers: N. Kabachenko, A. Mekshun, T. Ostrianko, N. Saiko, M. Yakovliev, L. Beddoe, D. J. Greenwood, M. Levin, T. May, P. Marsh, M. Fisher and etc.

The study of the application of the research-based training system is devoted to the numerous works of foreign researchers: M. Gosper, D. Ifenthaler, P. Levy, J. E. Mills, R. Petrulis, M. Prince, D. F. Treagust, R. Felder and etc.

The purpose of the paper is to analyse educational systems of research-based training systems of specialists in Germany and to identify the effective elements for improving the Ukrainian education system.

Research-based training system. The researchbased training has become widely developed in foreign higher educational institutions, but, unfortunately, in Ukraine this issue has been given little attention. Research-based training is seen as a fragmentary form of training organization, although it has long been proven that this type of active learning (Wildt, 2011; Ludwig, 2011), which is implemented through specific forms, has its own indicators and characteristics. In addition, research-based training is an umbrella tern that covers a range of pedagogical approaches in the process of student's professional development aimed at developing research skills (formulation and problem-solving) (Aditomo et al., 2013).

On the basis of the research results, scholars are defined the research-based training as a type of learning that has its purpose, content, methods, form of organization and means, and can be implemented through a specific set of learning technologies. Confirmation of such an opinion is found in the works of well-known foreign scientists, whose research was related to the methodological basis of research-based training (Pavliuk et al., 2017).

Research-based training is a complex of pedagogical goals, which are united with the main tasks in the development of research competence of students (development of skills for setting the research task and finding ways to solve it) (Pavliuk et al., 2017).

Educational systems for training specialists in the social sphere on a research basis at universities in Germany. The Federal Republic of Germany brings together 326 higher education institutions, the vast majority of which are state-owned (non-state law enforcement agencies are required to hold a state-licensed teaching license). The basis of the system are universities (Universitaet) and equated with them higher education institutions: classical universities (faculties of medicine, humanities and natural sciences, theology, sociology, economics, agriculture and forestry, engineering), technical universities (Technische Universitaet) (engineering), general universities (Gesamthochschulen) (special vocational education and research), pedagogical institutes (Paedagogische Hochschulen), medical colleges, philosophical theological and church colleges (Theologische Hochschule), college of sports. Nonuniversity higher education institutions include vocational schools (Fachhochschulen) (vocational education in business, economics, service, agriculture and applied arts) and colleges of art (Kunsthochschule and Musikhochschule) (Sysoieva, Krystopchuk, p. 118).

All institutions of higher education are divided into the following groups: universities (classical, technical, general), as well as specialized institutions of the university level (higher schools for the training of teachers, theologians, doctors, etc.) (group A); higher professional schools with specialized training, (group B); higher schools (colleges) of arts and music (group C) (Sysoieva, Krystopchuk, p. 114). 
In our study several educational systems for the training of future specialists of social sphere on the basis of research-based training system have been analyzed at leading universities in Germany - University of Cologne (Cologne), University of Humboldt (Berlin).

The University of Cologne (Cologne, Germany) is one of Germany's largest universities in terms of the number of students (about 50,000 students). The university was founded in 1388, but in 1799 it was closed, and all attempts during the nineteenth century to restore it were unsuccessful. The university's new history of activities began in 1919 with the construction of new buildings and the restoration of education. Today it is a powerful educational and scientific institution, which consists of 6 faculties and a huge number of bachelor's, masters and doctoral programs.

Among the structure of the University of Cologne, we will highlight the Humanities Faculty, which prepares specialists in the social sphere. At the master's level, such programs are: Master of Education for Special Educational Needs, Master of Rehabilitation, Master of Prevention and Early Intervention. Studying in the magistracy lasts two years and involves studying subjects in the volume of 120 credits. Consider a more detailed structure of the listed educational programs for training specialists in the social sphere.

The Master of Education for Special Educational Needs includes a close link between theory and practice, teacher training in accordance with modern requirements, types of schools and special classes. The training involves the study of two blocks of special education disciplines and two disciplines that deepen the specialty (selective disciplines and specialization). The training system is aimed at developing competency profile for school education, evaluation and diagnosis of pupils, tutors and guardians. The Master's program is also aimed at forming a tolerant attitude to the social and cultural diversity of modern society, the formation of tolerance among students, tutors, etc. Applicants have the right to study for this educational program by their previous (Bachelor) pedagogical education.

Master of Rehabilitation. This educational program involves the training of a specialist on complex and individual rehabilitation of people with disabilities, chronic illnesses. All disciplines of the educational program are aimed at work in institutions for people with disabilities, in rehabilitation centres and services, in health and social work institutions, in educational and training establishments, migration services and international institutions, higher education institutions, pre-school educational establishments, etc. The program provides the opportunity to develop individual training profiles for different categories of educational services recipients.

Masters in Rehabilitation are studying two main modules and additional modules for correctional education, social sciences, psychology and medicine. In addition, two types of practice are foreseen. Among the first specialization block, the student can choose: psychomotor development as early childhood care (the main focus of the program is the educational support of children, aimed at the development of psychomotorics), educational support and social work in the field of youth well-being and juvenile justice (professional education support and legal aid for young people who find themselves in difficult living conditions). The main focus is the study of forms of deviant behaviour, the study of offenses and work in the multidisciplinary team, prevention and professional rehabilitation (the main focus is the support of young people with disabilities at the transition from education to work, also in the field of public health and work of people with disabilities and health problems), rehabilitation scientific gerontology (coordination of work in gerontological institutions and related spheres of activity, support of the elderly, taking into account the special conditions and needs of such people and people with disabilities in the corresponding institutions), organizational (professional) development in rehabilitation (professional development of employees of rehabilitation institutions and centres, developing a system for monitoring and evaluating the activities of such institutions, assessing the quality of providing services to rehabilitation centres / institutions).

The second block envisages the following specialization: rehabilitation of people with complex disorders (therapy and care for people with various injuries and violations), rehabilitation of hearing impaired people (education and rehabilitation of hearing impaired at different age stages, psychosocial and professional rehabilitation and support), rehabilitation of people with cognitive impairments (medical and compensatory work with people of different ages with cognitive impairments - general educational disability, reading and writing disorders, genetic disorders, dementia), rehabilitation of people with mental disorders (focus of the program - to plan, implement and evaluate the concepts of intervention and treatment for people with mental health problems of different age stages).

Master of Prevention and Early Intervention is specialist in the field of purposeful intervention in development, primary prevention of early development of protective factors for the purpose of general health promotion or minimization of developmental risks. In addition, the Master's program in Prevention and Early Intervention provides for secondary and tertiary prevention - interventions and therapies at a time when deviations already exist, health promotion aimed at preventing already existing violations and avoiding the following disorders.

Masters of Preventiveand Early Interventionactivities include pre-school education, disability assistance, early childhood care, health policy management, counselling centres, social pediatric centres, health facilities, and inclusive educational institutions.

This Master's program provides students with scientific research aimed at developing professional, methodological, social and personal competences for multimodal prevention and intervention in the 
development of vulnerable children and their families based on the theory and evidence that contribute to the health of such children and their families. Master's work must be carried out using a wide range of research methods and theories present a practical solution to the academic problem and have further scientific predicted development.

This result is achieved through the application of a research-based training system and a «learned-practice» model. This system and model is provided by two modules, «Statistics and Evaluation» and «Practice of research and prediction of quality». Students study these modules in 1 and 2 semesters, while the 3rd semester is entirely devoted to internships, during which the student conducts research, develops applied and restrictive research questions and completes the work in the 4th semester.

As you can see, not all Master's programs in the University of Cologne provide a research-based training system. This is due to the fact that some programs are purely practice-oriented and involve the formation of professional qualities. However, while studying at any master's program, a student may additionally choose a master's research program that involves purely scientific and research training. It lasts for only a year and during parallel training under such a program the student studies the methodology of scientific research and conducts his own research on the relevant field of knowledge.

The University of Humboldt (Berlin, Germany) was founded in 1809 by Wilhelm von Humboldt. There are about 30,000 students studying at the university at 11 faculties. Preparation at this university takes place in a very large number of undergraduate and master's programs. Among them, it is worthwhile to highlight the programs that are relevant to our study: Master of Rehabilitation Education, Master of Special Education (Sign Language), Master of Social Sciences, etc.

Let's dwell on the structure of the master's degree program in social sciences. Students are offered five modules: M1 - Theories and Methods of Social Sciences; M2 - Specialization; M3 - Project module; M4 and M5 - free choice in the field of social sciences. The final stage of the training is the final colloquium.

Theories and methods of social sciences are divided into two separate submodules - theories and methods. Theories of social sciences include the study of students' actual social problems, the basics of criticism (Marx, Nietzsche, Freud) and the «crisis» theory and a complex case. Methods of social sciences include the study of qualitative research methods in the development of cases, quantitative research methods: cross-sectional analysis of data.

From the specialization the student can choose: political and social theories, social and political inequality, democracy, labour and spheres of life, migration and urbanization. Within the framework of the project module students are offered the study of such disciplines: discussion and expertise (political theories and theories of ideas), cultural centres in the post-industrial city (urbanization), sociology of borders, social inequality, violence and international law. Modules 4 and 5 - free choice in social sciences - offer students a wide range of disciplines, which they choose on their own. Accordingly, the final colloquiums cover the disciplines students have chosen on their own.

Of course, studying for the master's degree program in social sciences ends with the defense of master's work. Performing a master's work requires a student to conduct a qualitative and thorough study using a wide range of theories and research methods. It is noteworthy that according to the results of the study of the first module (Theories and Methods of Social Sciences), the student must determine the subject of his research and, accordingly, already chooses a specialization and a discipline of free choice. Specialization and discipline of free choice should help the student correctly formulate the hypothesis of the study, the task. In addition, the content of selected disciplines and specialization should be reflected in the master's study, that is, the discipline is chosen by the student not for their own development, but in order to present a qualitative and thorough study at the final stage of the training.

Comparing with the system of masters training at Ukrainian universities, we can confidently say that the subjects of the main and selective block disciplines for students are primarily aimed at developing its professional competence; for conducting research and final presentation of the master's thesis, only a few disciplines are offered on general research theories and methods of research. In the Humboldt University Master's program, we can observe an entirely opposite situation - all aimed at the student's specific research focus and should contribute to a qualitative and substantive study. Such an educational system can be confidently called research-based.

Conclusions. As a result, the analysis of educational systems for training specialists in the social sphere using research-based training system in universities in Germany, in particular the University of Cologne (Cologne, Germany) and the University of Humboldt (Berlin, Germany), we have found that not every Master's program envisages studying using research techniques. However, it was found that the research-based training system in its proper application, encompasses not just the student's research activity, partly detached from the educational process, but is reflected in each student's discipline. That is, each discipline reveals one of the aspects / tasks / directions of student research and in parallel serves as a practical basis for the development of professionally relevant competencies.

Prospects for further research we see the study of the individual research and educational trajectory of the student through the entire period of training in the system of training specialists in the social sphere using research-based training system and the development of methodological recommendations for the use of such a trajectory and system in the Ukrainian system of higher education. 


\section{References}

Aditomo, A., Goodyear, P., Bliuc, A.-M., Ellis, R. A. (2013). Inquiry-based learning in higher education: principal forms, educational objectives, and disciplinary variations. Studies in Higher Education, 38, $1239-1258$. DOI: 10.1080/03075079.2011.616584 (eng).

Beddoe, L. (2011). Investing in the Future: Social Workers Talk about Research. The British Journal of Social Work, 41, Issue 3, 557-575. DOI: https://doi.org/10.1093/bjsw/bcq138 (eng).

Greenwood, D. J., Levin, M. (2007). Introduction to Action Research: Social Research for Social Change. Thousand Oaks, USA: Sage Publication (eng).

Ifenthaler, D. \& Gosper, M. (2014). Research-based learning: connecting research and instructions. In M. Gosper, D. Ifenthaler (Eds.), Curriculum Models for the 21st Century: Using Learning technologies in Higher Education (pp. 73-89). New York, USA: Springer. DOI: 10.1007/978-1-4614-73-66-4_5 (eng).

Levy, P. \& Petrulis, R. (2012). How do first year university students experience inquiry and research, and what are the implications for the practice of inquiry-based learning? Studies in Higher Education, 37 (1), 85 -101 (eng).

Ludwig, J. (2011). Forschungsbasierte Lehre als Lehre im Format der Forschung. Retrieved from http://www.sqbrandenburg.de/files/bbhd03.pdf (ger).

Marsh, P., Fisher, M. (2008). The Development of Problem-Solving Knowledge for Social Care Practice. The British Journal of Social Work, 38, Issue 5, 971-987. DOI: https://doi.org/10.1093/bjsw/bcm116 (eng).

May, T. (2011). Social Research: Issues, Methods and Process. Berkshire, Great Britain: Open University Press (eng).

Mills, J. E. \& Treagust, D. F. (2003). Engineering education - Is problem-based or project-based learning the answer? Australasian Journal of Engineering Education. Retrieved from http://www.aaee.com.au/journal/2003mills treagust03.pdf (eng).

Pavliuk, R. O.; Liakh, T. L.; Bezpalko, O. V.; Klishevych, N. A. (2017). Research-based training: methodological characteristics and results of the analysis of educational programs. Social Sciences, 6 (4), 152. DOI: 10.3390/ socsci6040152 (eng).

Prince, M. J., \& Felder, R. M. (2006). Inductive teaching and learning methods: Definitions, comparisons, and research bases. Journal of Engineering Education, 95 (2), 123-138 (eng).

Wildt, J. (2011). 'Forschendes Lernen: Wie und Warum?', Presentation at Leibniz University Hannover, 13. October 2011. Retrieved from https://www.zqs.uni-hannover.de/fileadmin/institut/pdf/Forschendes_Lernen_Leibniz_ Universitaet_Hannover_Prof._Dr._Dr._Wildt_13.10.2011.pdf (ger).

Zvierieva, I. D. (Ed.) (2012). Entsyklopediya dlya fakhivtsiv sotsial'noyi sfery [Encyclopedia for professionals in the social sphere]. Kyiv, Simferopol, Ukraine: Universum (ukr).

Mekshun, A. D., Ostrianko, T. S. (2017). Istorychnyj ekskurs stanovlennja socialjnoji roboty ekonomichno rozvynutykh krajin z pidghotovky socialjnykh pracivnykiv [Historical excursion of the formation of social work of economically developed countries in training of social workers]. Problemy socialjnoji roboty: filosofija, psykhologhija, sociologhija, 1 (9), 54-61 (ukr).

Saiko, N. (2017). Systema profesijnoji pidghotovky socialjnykh pedaghoghiv u Nimechchyni [System of professional training of social pedagogues in Germany]. Vytoky pedaghoghichnoji majsternosti, 19, 385-390 (ukr).

Sysoieva, S. O., Krystopchuk, T. Ye. (2012). Osvitni systemy krajin Jevropejsjkogho Sojuzu: zaghaljna kharakterystyka [Educational systems of countries of the European Union: general characteristics]. Rivne, Ukraine: Ovid (ukr).

Yakovliev, M. V., Kabachenko, N. V. (2011). Osvita ta profesijna pidghotovka socialjnykh pracivnykiv: styslyj oghljad svitovoji praktyky [Education and training of social workers: a concise overview of world practice]. Naukovi zapysky NaUKMA. Pedaghoghichni, psykhologhichni nauky ta socialjna robota, 123, 54-60 (ukr).

\section{Література}

Aditomo A., Goodyear P., Bliuc A.-M., Ellis R. A. Inquiry-based learning in higher education: principal forms, educational objectives, and disciplinary variations. Studies in Higher Education. 2013. № 38. P. $1239-1258$. DOI: $10.1080 / 03075079.2011 .616584$.

Beddoe L. Investing in the Future: Social Workers Talk about Research. The British Journal of Social Work. 2011. Vol. 41. Issue 3. P. 557-575. DOI: https://doi.org/10.1093/bjsw/bcq138.

Greenwood D. J., Levin M. Introduction to Action Research: Social Research for Social Change. Thousand Oaks: Sage Publication, 2007. 288 p.

Ifenthaler D., Gosper M. Research-based learning: connecting research and instructions. M. Gosper, D. Ifenthaler (Eds.). Curriculum Models for the 21st Century: Using Learning technologies in Higher Education. New York: Springer, 2014. P. 73-89. DOI: 10.1007/978-1-4614-73-66-4_5.

Levy P., Petrulis R. How do first year university students experience inquiry and research, and what are the implications for the practice of inquiry-based learning? Studies in Higher Education. 2012. № 37 (1). P. 85 -101.

Ludwig J. Forschungsbasierte Lehre als Lehre im Format der Forschung. Potsdam: Universitätsverlag Potsdam, 2011. URL: http://www.sq-brandenburg.de/files/bbhd03.pdf (дата звернення 01.12.2018). 
Marsh P., Fisher M. The Development of Problem-Solving Knowledge for Social Care Practice. The British Journal of Social Work. 2008. Vol. 38. Issue 5. P. 971-987. DOI: https://doi.org/10.1093/bjsw/bcm116.

May T. Social Research: Issues, Methods and Process. Berkshire: Open University Press, 2011. 320 p.

Mills J. E., Treagust D. F. Engineering education - Is problem-based or project-based learning the answer? Australasian Journal of Engineering Education. 2003. Vol. 3. Issue 2. P. 2-16. URL: http://www.aaee.com.au/ journal/2003mills_treagust03.pdf (дата звернення 21.12.2018).

Pavliuk R. O., Liakh T. L., Bezpalko O. V., Klishevych N. A. Research-based training: methodological characteristics and results of the analysis of educational programs. Social Sciences. 2017. № 6 (4). P. 152. DOI: 10.3390/ socsci6040152.

Prince M. J., Felder R. M. Inductive teaching and learning methods: Definitions, comparisons, and research bases. Journal of Engineering Education. 2006. Vol. 95. Issue 2. P. 123-138.

Wildt J. 'Forschendes Lernen: Wie und Warum?', Presentation at Leibniz University Hannover, 13. October 2011. URL: https://www.zqs.uni-hannover.de/fileadmin/institut/pdf/Forschendes_Lernen_Leibniz_Universitaet_ Hannover_Prof._Dr._Dr._Wildt_13.10.2011.pdf (дата звернення 21.12.2018).

Енциклопедія для фахівців соціальної сфери / І. Д. Звєрєва (ред.). Київ, Сімферополь: Універсум, 2012. 536 с.

Мекшун А. Д., Острянко Т. С. Історичний екскурс становлення соціальної роботи економічно розвинутих країн з підготовки соціальних працівників. Проблеми соціальної роботи: філософія, психологія, соціологія. 2017. № 1 (9). С. 54-61.

Міністерство освіти і науки України. Інклюзивне навчання. Статистичні дані. URL: https://mon.gov.ua/ua/ statistichni-dani (дата звернення 01.12.2018).

Сайко Н. Система професійноїпідготовки соціальних педагогів у Німеччині. Витоки педагогічноїмайстерності. 2017. № 19. С. 385-390.

Сисоєва С. О., Кристопчук Т. Є. Освітні системи країн Європейського Союзу: загальна характеристика. Рівне: Овід, 2012. 352 с.

Яковлєв М. В., Кабаченко Н. В. Освіта та професійна підготовка соціальних працівників: стислий огляд світової практики. Наукові записки НаУКМА. 2011. Том 123. Педагогічні, психологічні науки та соціальна робота. С. 54-60.

\section{ПІДГОТОВКА ФАХІВЦІВ СОЦІАЛЬНОЇ СФЕРИ НА ДОСЛІДНИЦЬКІЙ ОСНОВІ В НІМЕЧЧИНІ}

Павлюк Роман, кандидат педагогічних наук, доцент, заступник директора з науково-методичної та навчальної роботи Інституту людини, доцент кафедри англійської мови факультету права та міжнародних відносин,

Київський університет імені Бориса Грінченка, бульв. Ігоря Шамо, 18/2, 02152 Київ, Україна, r.pavliuk@kubg.edu.ua

У статті розглянуто освітні системи підготовки фахівців соиіальної сфери на досліднищькій основі в Німечиині. Навчання на досліднищькій основі - це об'єднувальне поняття, яке охоплює ряд педагогічних підходів у процесі професійної підготовки студентів, спрямованої на розвиток дослідницьких умінь (постановка та вирімення завдань). На основі досліджень зарубіжних вчених та попередніх досліджень автора визначено, що система навчання на дослідницкій основі - це комплекс педагогічних иілей, які об'єднанні основним завданням у розвиткові дослідницької компетентності студентів (розвиток умінь постановки дослідницького завдання та пошук шляхів його вирішення). Проаналізовано систему підготовки фахівців соціальної сфери на дослідницькій основі у двох провідних університетах Німеччини - Кельнський університет (м. Кельн, Німеччина) та Університет імені Гумбольдта (м. Берлін, Німеччина), а також проведено порівняння із системою підготовки магістрів в українських університетах. Встановлено, що не кожна магістерська програма передбачає навчання із застосуванням дослідницьких технік. Проте з'ясовано, що система навчання на дослідницькій основі при своєму правильному застосуванні охоплює не просто науково-досліднищьку діяльність студента, почасти відірвану від освітнього процесу, а знаходить своє відображення у кожній виучуваній студентом дисиипліні. Кожна дисиипліна розкриває один з аспектів / завдань / напрямків досліджень студентів і паралельно служить практичною основою для розвитку професійно значущих компетентностей. Перспективами подальших досліджень убачаємо вивчення індивідуальної дослідницької та освітньої траєкторії студента через увесь період навчання у системі підготовки фахівиів соціальної сфери на дослідницькій основі та розроблення методичних рекомендацій використання такої траєкторії та системи в українській системі вищої освіти.

Ключові слова: освітня система; професійна підготовка; система навчання на дослідницькій основі; фахівець соціальної сфери. 


\section{ПОДГОТОВКА СПЕЦИАЛИСТОВ СОЦИАЛЬНОЙ СФЕРЫ НА ИССЛЕДОВАТЕЛЬСКОЙ ОСНОВЕ В ГЕРМАНИИ}

Павлюк Роман, кандидат педагогических наук, доцент, заместитель директора по научно-методической и учебной работе Института человека, доцент кафедры английского языка Факультета права и международных отношений,

Киевский университет имени Бориса Гринченко,

бульв. Игоря Шамо, 18/2, 02154 Киев, Украина,

r.pavliuk@kubg.edu.ua.

В статье рассмотрены образовательные системь подготовки специалистов социальной сферы на исследовательской основе в Германии. На основе исследований зарубежных ученых и предыдущих исследований автора определено, ито система обучения на исследовательской основе - это комплекс педагогических иелей, которые объединении основной задачей в развитии исследовательской компетентности студентов (развитие умений постановки исследовательской задачи и поиск путей ее решения). Проанализирована система подготовки специалистов социальной сферы на исследовательской основе в двух ведущих университетах Германии - Кельнский университет (2. Кельн, Германия) и Университет имени Гумбольдта (г. Берлин, Германия). Установлено, что не каждая магистерская программа предусматривает обучение с применением исследовательских техник. Однако установлено, ито система обучения на исследовательской основе в своем правильном применении охватывает не просто научно-исследовательскую деятельность студента, отчасти оторванную от образовательного процесса, а находит свое отражение в каждой изучаемой студентом дисииплине.

Ключевые слова: образовательная система; профессиональная подготовка; система обучения на исследовательской основе; специалист социальной сферы.

Стаття надійшла до редакиії 10.02.2019

Прийнято до друку 25.04.2019 